\title{
Frances Back
}

\section{Gott als Vater der Jünger im Johannesevangelium}

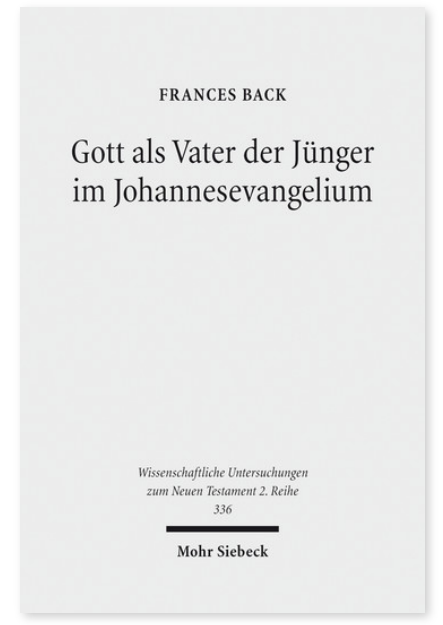

2012. X, 239 Seiten. WUNT II 336

ISBN 978-3-16-152287-1

DOI 10.1628/978-3-16-152287-1

eBook PDF $89,00 €$

ISBN 978-3-16-152262-8

fadengeheftete Broschur 89,00€
In der johanneischen Theologie tritt die Rede von Gott als »dem Vater « im Gegenüber zu »dem Sohn« besonders hervor, ebenso die Rede von der Gotteskindschaft der Glaubenden (Joh 1,12). Doch fällt dabei auf, dass im Johannesevangelium erst in 20,17, im Rahmen der österlichen Erscheinungen, explizit von Gott als Vater der Jünger gesprochen wird. In einem exegetischen Durchgang durch die johanneischen Abschiedsreden, in denen das Verhältnis zwischen den Jüngern und Gott im Horizont des bevorstehenden Todes Jesu behandelt wird, und in der Analyse der einschlägigen Passagen der johanneischen Ostererzählungen bestimmt Frances Back die Bedeutung der Rede von Gott als Vater der Jünger für die Komposition und Theologie des Johannesevangeliums näher.

Frances Back (1967-2012) 2002 Dr. theol. (Tübingen); 2008 Habilitation (Göttingen); war Privatdozentin für Neues Testament an der Universität Göttingen und Pfarrerin der Badischen Landeskirche.

Jetzt bestellen:

https://mohrsiebeck.com/buch/gott-als-vater-der-juenger-im-johannesevangelium-9783161522871?no_cache=1 order@mohrsiebeck.com

Telefon: +49 (0)7071-923-17

Telefax: +49 (0)7071-51104 